УДК 378.016:811.111’36

OKSANA DANYLENKO

https://orcid.org/0000-0003-3937-9110

odanylenko@gmail.com

Postgraduate Student

Ternopil Volodymyr Hnatiuk National Pedagogical University

Ternopil, 2 Maksyma Kryvonosa St.

\title{
DEVELOPING GRAMMATICAL COMPETENCE OF PROSPECTIVE TEACHERS LEARNING ENGLISH AFTER GERMAN THROUGH INDEPENDENT WORK ACTIVITIES
}

The article deals with the problem of developing the a subsystem of exercises for forming productive grammatical competence of prospective teachers learning English after German through independent work activities. The importance of transfer based on previously acquired knowledge and skills in German and its influence on the process of forming prospective teachers' English grammatical competence has been emphasized. The necessity to consider this factor when developing exercises for independent work has been shown. The principles of developing the subsystem of exercises for forming productive grammatical competence have been identified. The requirements the exercises should meet have been analyzed and the stages of the process of forming grammatical competence (preparatory, stereotypical and variational) have been identified in the process of designing the subsystem of exercises. The suggested subsystem of exercises includes three groups of exercises corresponding to the stages of the grammatical competence forming. The types of exercises in each group have been specified. The examples of exercises have been provided in the article. All groups of exercises provide tasks for the development of prospective teachers' contrastive skills to identify similar phenomena in the systems of English and German languages, as well as for the development of reflection in the process of comparing speech phenomena on the one hand and the results of learning on the other. The third group of exercises engages communicative tasks. The presented subsystem is an instrument for organizing independent work of students with grammatical material.

Keywords: grammatical competence, productive grammatical skills, subsystem of exercises, prospective teachers, second foreign language.

\section{ОКСАНА ДАНИЛЕНКО}

аспірантка

Тернопільський національний педагогічний університет імені Володимира Гнатюка м. Тернопіль, вул. Максима Кривоноса, 2

\section{ФОРМУВАННЯ ГРАМАТИЧНОЇ КОМПЕТЕНТНОСТІ МАЙБУТНІХ УЧИТЕЛІВ У ПРОЦЕСІ НАВЧАННЯ АНГЛІЙСЬКОЇ МОВИ ПІСЛЯ НІМЕЦЬКОЇ ЗА ДОПОМОГОЮ ВПРАВ ДЛЯ САМОСТІЙНОЇ РОБОТИ}

Розглянуто особливості формування продуктивної граматичної компетентності майбутніх учителів у процесі навчання англійської мови після німецької за допомогою підсистеми вправ для самостійної роботи. Проаналізовано трактування структури граматичної компетентності та ї̈ компонентів. Досліджено підходи до виокремлення етапів формування граматичної компетентності в сучасній науковій літературі. Визначено, щзо $з$ метою підвищення ефективності формування продуктивної граматичної компетентності студентів при розробиі вправ потрібно враховувати вплив раніше засвоєних студентами знань та навичок з німецької мови. Встановлено, щзо досягнення студентами належного рівня англомовної граматичної компетентності можливе за умови ефективної організації самостійної роботи, спрямованої на максимальне використання позитивного переносу 3 німецької мови. Обтрунтовано принщипи розробки підсистеми вправ для самостійної роботи 3 формування продуктивних граматичних навичок у процесі навчання другої іноземної мови: відповідність типів $i$ видів вправ певному виду мовленнєвої діяльності $i$ комунікативним умінням, урахування позитивного взаємовпливу різних видів мовленнєвої діяльності, врахування можливостей переносу та інтерферениії, забезпечення реалізації творчої самостійної роботи та можливостей для розвитку граматичної усвідомленості студентів. У процесі розробки підсистеми вправ проаналізовано вимоги до вправ для формування граматичних навичок та виокремлено підготовчий, стереотипний $і$ варіативний 
етапи формування граматичної компетентності. Відповідно до визначених етапів у підсистемі вправ для самостійної роботи з формування продуктивної граматичної компетентності майбутніх учителів у процесі навчання англійської мови після німецької були визначено три групи вправ, в кожній з яких конкретизовано види вправ, спрямовані на ознайомлення з новими граматичними структурами та їх відтворення, автоматизацію дій студентів із новими граматичними структурами на рівні словоформи, словосполучення, фрази/речення понадфразової єдності i тексту у прочесі говоріння та письма. Наведено приклади вправ з кожної групи підсистеми. Всі групи вправ передбачають завдання для розвитку контрастивних умінь визначати схожі явища у системах англійської та німецької мов, а також для розвитку рефлексї̈ у проиесі зіставлення мовних явищ з одного боку та результатів навчання з іншого. Третя група вправ передбачає залучення комунікативних завдань. Відзначено, щзо представлена підсистема є інструментом організаиї̈ самостійної роботи студентів з граматичним матеріалом.

Ключові слова: граматична компетентність, продуктивні граматичні навички, підсистема вправ, майбутні вчителі, друга іноземна мова.

ОКСАНА ДАНИЛЕНКО

аспирантка

Тернопольский национальный педагогический университет имени Владимира Гнатюка

г. Тернополь, ул. Максима Кривоноса, 2

\title{
ФОРМИРОВАНИЕ ГРАММАТИЧЕСКОЙ КОМПЕТЕНТНОСТИ БУДУЩИХ УЧИТЕЛЕЙ В ПРОЦЕССЕ ОБУЧЕНИЯ АНГЛИЙСКОМУ ЯЗЫКУ ПОСЛЕ НЕМЕЦКОГО С ПОМОЩЬЮ УПРАЖНЕНИЙ ДЛЯ САМОСТОЯТЕЛЬНОЙ РАБОТЫ
}

\begin{abstract}
Рассмотрены особенности формирования продуктивной грамматической компетентности будущих учителей в процессе обучения английскому языку после немецкого с помощью подсистемы упражнений для самостоятельной работы. Проанализированы трактовки структуры грамматической компетентности. Исследованы подходы к выделению этапов формирования грамматической компетентности в современной научной литературе. Определено, что для повышения эффективности формирования продуктивной грамматической компетентности студентов при разработке упражнений нужно учитывать влияние ранее усвоенных студентами знаний и навыков по немецкому языку. Обоснованы принципь разработки подсистемы упражнений для самостоятельной работь по формированию продуктивных грамматических навыков в процессе обучения второму иностранному языку. Проанализированы требования к упражнениям для формирования грамматических навыков $и$ выделены подготовительный, ситуативный и вариативный этапь формирования грамматической компетенции. Согласно определенным этапам в подсистеме упражнений для самостоятельной работь по формированию продуктивной грамматической компетентности будущзих учителей в процессе обучения английскому языку после немечкого были определены три группы упражнений. Приведены примеры упражнений из каждой группы подсистемы. Все группы упражнений предусматривают задание для развития контрастивных умений определять сходные явления в системах английского и немечкого языков, а также для развития рефлексии в процессе сопоставления языковых явлений с одной сторонь и результатов обучения с другой. Третья группа упражнений предусматривает привлечение коммуникативных заданий. Отмечено, что представленная подсистема является инструментом организации самостоятельной работь студентов с грамматическим материалом.
\end{abstract}

Ключевые слова: грамматическая компетентность, продуктивные грамматические навыки, подсистема упражнений, будущие учителя, второй иностранный язык.

The rapid growth in academic mobility facilitates international relations and therefore students learn more than one foreign language. Students of higher educational institutions whose major is German usually study English as a second foreign language and are going to become teachers of German and English. The students' performance in the English language is greatly affected by their progress in acquiring English grammar. The question of forming grammatical competence in teaching English after German has become the issue of concern of foreign language teaching.

The problem of teaching grammar has been studied by O. I. Vovk, N. K. Skliarenko, L. M. Chernovatyi, R. Dirven, J. Scrivener and others. Different aspects of forming grammatical competence while teaching second foreign language have been regarded by A. O. Andrushchenko, 
A. O. Anisimova, I. L. Bim, V. A. Myskiv, B. A. Lapidus, G. de Angelis, R. Ellis, H. Ringbom, and others. The issues of forming grammatical competence within students' independent work have been presented in works by O. P. Brusianina, I. P. Zadorozhna, D. Little and others. Nevertheless, the questions concerning the methodology of forming grammatical competence in teaching English as a second foreign language with regard to independent work are still to be explored.

The purpose of the article is to ground the subsystem of exercises for the development of productive grammatical competence of prospective teachers learning English after German through independent work activities.

The search for the best ways to teach grammar has generated a number of approaches to teaching grammar. Each approach has enriched the practice of foreign language teaching with certain types of activities. One of them is translation-based approach related to traditional grammar that is represented in teaching languages by grammar-translation method. Quite opposite to grammartranslation method emerged the direct method which was based on naturalistic approach and represented foreign language teaching only using the foreign language itself. The development of structuralism and behaviorist learning theory led to audio-lingual method that presented pattern drills in teaching foreign languages. The rise of transformational-generative grammar and pragmatics facilitated the appearance of communicative approach in teaching foreign languages and introduced the notion of communicative competence. Nowadays the teaching of foreign languages is determined by communicative and cognitive approaches [6, p. 5-9]. Thus, teaching grammar is predetermined by communicative and cognitive approaches as well and consequently realized through foreign language practice. One of the components of communicative competence is grammatical competence.

The aim of teaching practical grammar is the formation of grammatical competence of prospective teachers of foreign languages. According to the Common European Framework of Reference for Languages, grammatical competence is defined as knowledge of grammatical resources of a language and ability to use them [1, p. 112].

N. K. Skliarenko considers grammatical competence as ability of a person to produce correct oral and written utterances in accordance with grammar rules and to understand grammatical structures used in speaking by others. These processes of production and understanding are based on complex and dynamic interaction of relevant skills, knowledge and awareness. That is why the scientist views grammatical skills, grammatical knowledge, and grammatical awareness as the main components of grammatical competence [5, p. 15].

Speaking about grammatical knowledge, we mean the scope of grammar that should be covered by syllabus. That is why scientists differentiate between linguistic and pedagogical grammar. Linguistic grammar provides scientific linguistic description of grammatical system of a certain language. Whereas pedagogical grammar is "a cover term for any learner- or teacher-oriented description or presentation of foreign language rule complexes with the aim of promoting and guiding learning processes in the acquisition of that language" [6, p. 1]. Hence pedagogical grammar organizes the grammatical material to be learned according to the criteria of foreign language teaching methods and provides the basis for practical grammar taught in integrated classes of English as a second foreign language.

Acquisition of grammatical knowledge is connected with mastering grammatical forms. Learners separate and choose grammatical forms by recognizing features of a structure. N. K. Skliarenko defines the grammatical structure as "an abstract scheme that represents relations between the components of speech units" [4, p. 143]. There are the following speech units: word-form, word combination, phrase/sentence, supra-phrasal unit, and text [4, p. 143]. The effectiveness of studying English grammar in some way may be facilitated or vice versa hampered by students' acquired knowledge about grammatical forms in German.

The next component of grammatical competence is grammatical skills. The grammatical skills are formed gradually; they have to be automatic, flexible and steady [3, p. 239]. The scientists differentiate between receptive grammatical skills and productive grammatical skills. It is important for students to develop receptive grammatical skills in order to perceive and understand oral and written utterances. Well-developed receptive grammatical skills help students to succeed in listening and reading. Receptive grammatical skills include mental operations of perceiving grammatical structure in sound or graphical form, recognizing these forms and correlating them with certain meaning. Productive grammatical skills are the basis for the ability to express own opinions and thoughts in oral and written forms, that is students' performance in speaking and writing is determined 
by the level of the development of productive grammatical skills. Productive grammatical skills comprise mental operations of choosing grammatical structures that are proper in a particular situation, processing of chosen grammatical structures according to the language norms, and realization in speech [3, p. 240].

J. C. Richards views language transfer as the influence of a native language on learning English based on similar forms or linguistic features of both languages. Hence the interaction of grammatical skills results in the processes of positive transfer or negative transfer (interference). As an example he suggests that the learners whose native language is German will probably have less difficulty in acquiring English definite and indefinite articles [11, p. 273-274]. We consider this observation important not only for the transfer or interference from the native language to the foreign one, but also for the transfer and interference as a result of interaction of a previously acquired foreign language and newly learned languages. The transfer of morphological and syntactical skills from German as a first foreign language has to facilitate acquiring morphological and syntactical peculiarities of English.

Grammatical awareness as a part of language awareness of a person is the ability of a learner to analyze grammatical structure of a language and to have own reflections on the way grammatical structures function and how they are produced. At the same time grammatical awareness implies that the learner is aware of his or her own processes of learning and language acquisition [3, p. 240]. In our case learner's grammatical awareness imply that students are able to deduce how their prior grammatical skills correlate to those they acquire in English.

The process of forming grammatical competence and acquiring grammatical skills needs executing certain teaching and learning actions in the form of an exercise.

The exercise is viewed as "especially organized under teaching conditions multiple executions of separate operations, actions or activities with the purpose of acquiring foreign language communicative competence or its components" [3, p. 181]. Exercises constitute different types of systems of exercises. The general system of exercises provides forming foreign language communicative competence as a whole. The particular systems of exercises provide forming one of the speech activities: listening, speaking, reading or writing. The subsystem of exercises is determined to develop certain skills and gain knowledge necessary for developing speech skills and includes appropriate groups of exercises [3, p. 189]. For example, teaching speaking presupposes subsystems for acquiring grammatical, lexical and pronouncing skills, when writing includes subsystems for acquiring grammatical, lexical skills and writing techniques. We deal with the subsystem of exercises since our work is focused on forming productive grammatical skills. It is important to consider the type of speech activity and corresponding to it communicative skills and language knowledge while selecting the types of exercises for the subsystem. The positive mutual influence of different types of speech activities in teaching process and the interrelation between different language and speech competencies should be taken into account [3, p. 189]. So developing grammatical skills in speaking has to be combined with activities in reading, listening and writing. Teaching grammatical skills in writing in its turn has to include activities in speaking, reading and listening.

There are general requirements to exercises, so they should provide the motivation factor for students to perform speech actions; be maximum oriented to communicative aims; consider aspects of culture of the studied language; correspond to prospective teachers professional aims; be supplied with the necessary supporting aids; organize the teaching process in the most favourable way relevant to the aim of this process [4, p. 153].

Besides general requirements, exercises also have to meet special requirements derived from their structure and purpose. Thus, developing exercises, teacher should provide a clearly stated speech task; the utterances and phrases in the exercise should be selected in correlation to a natural or artificial teaching situation; the aim and the content of the utterance have to become the focus of students' attention; the acquisition of grammatical skills should go in connection with the development of necessary pronunciation and lexical skills; the phrases chosen for the exercise should bear certain communicative value; on the whole the exercise should provide grammatical accuracy and sufficient number of phrases [4, p. 153].

We would also like to add the principles of taking into account the possibilities of transfer on the basis of contrasting language systems, providing possibilities for students' independent work and raising students' grammatical awareness. 
The basic issue for the development of the subsystem of exercises for forming productive grammatical skills is to define the stages of learning and teaching grammar.

Scholars identify the stage of orientation and preparation, the stereotype and situation based stage, and variation and situation based stage in the process of forming speech skills [3, p. 244].

T. Hedge describes the processes that constitute acquisition in terms of "the input hypothesis and the notion of intake" [9, p. 146]. She states that first of all learners notice specific features of the language and start to interpret the relationship between the form and the meaning of the noticed item.

Then goes the stage of reasoning and hypothesizing when learners deduce the meaning of what they hear or want to say applying the rules. This stage also includes contrastive analysis that helps the learners to understand certain issues by comparison of the languages they know and the new one. Translation is regarded by T. Hedge as a helpful strategy for better acquisition on this stage. Transferring on this stage results in applying by learners the knowledge of the language they already know to the production of the newly learned language [9, p. 146-147].

At the next stage the new rules, which the learners work out, structure and restructure learners' understanding of English grammar. The errors are peculiar to this stage due to the overgeneralization or influence of the prior languages [9, p. 147].

Then goes automatizing which results in "regular and consistent responses in conversation to a certain type of input" [9, p. 149]. This stage presupposes repeated practice of a correct form of use that facilitates communication and through this practice the explicit knowledge of grammar becomes implicit and the process of production becomes automatic. Though the author warns against the so called premature practice and appeals to the idea of readiness for learning. As an indicator of such practice T. Hedge suggests the students' failure to produce a form after they practiced it in the class later during the following classes. So the eventual automatization depends on students' readiness and the process of acquisition needs timing [9, p. 149-150].

One more approach to the stages of work with new grammatical structures is suggested by N. K. Skliarenko. The first stage is introduction. At this stage the grammar structure is demonstrated in the context and explained by the teacher or examples are analyzed by students with the help of the heuristic conversation conducted by a teacher. The introduction presupposes the use of different kinds of teaching information. The next stage is automatization of students' actions with word-forms, word combinations, and phrases/sentences. The third stage is the stage of automatization of students' actions involving them to work with supra-phrasal units and texts [4, p. 144].

Taking into account the mentioned above approaches to the process of forming grammatical competence, we distinguish preparatory stage, stereotypical stage and variational stage of forming productive grammatical competence.

Since the productive grammatical skills imply that the learner is able to choose proper morphological and syntactical forms for written or oral speech units, each stage introduces exercises of certain type that correlate to the tasks and actions to be performed at the corresponding stage.

The preparatory stage, in our case, is aimed at imitation of grammatical structures in oral or written forms. Nevertheless the crucial point of this stage is to point out the cases of negative transfer and interference on the initial stages of producing new grammatical structures. The teacher has to emphasize on major differences in two languages using the contrastive presentation and the students have to be provided with materials containing contrastive descriptions for their independent work. That is why we consider it reasonable to include elements of receptive activities such as recognition, differentiation, and identification. For example presenting the structure of naming person's occupation it is important to emphasize on the difference in using indefinite article in English and German:

- In English: I am $\boldsymbol{a}$ student. Anna is $\boldsymbol{a}$ doctor.

- In German: Ich bin Student. Anna ist Ärztin.

The stereotypical stage implies automatizing of earlier perceived grammatical structures by practicing their usage on the level of morphological forms, phrases and sentences, and consequently building speech stereotypes. At this stage it is important to reduce the influence of interference from the previously learned languages by means of presenting the possible ways for positive influence of transfer that even can facilitate better and faster acquisition of new grammatical structures.

The variational stage is the stage automatizing new grammatical structures on the level of discourse and text in dialogues, monologues and in different forms of writing. The variational stage has to result in consolidation of knowledge. This stage implies automatizing the use of new 
grammatical structures in different contexts, developing grammatical awareness and accomplishing heuristic and creative tasks dedicated to the students' independent work.

Consequently we derived the subsystem of exercises for forming productive grammatical competence in English as a second foreign language in the process of independent work. The subsystem consists of three groups and each group corresponds to one of the stages of productive grammatical competence acquisition: writing;

1) the group of exercises for familiarization with new grammatical structures in speaking and

2) the group of exercises for automatizing new grammatical structures on the level of a wordform, a word combination, and a phrase/sentence in speaking and writing;

3 ) the group of exercises for automatizing new grammatical structures on the level of discourse in different communicative situations.

Developing the subsystem of exercises, besides the types of exercises suggested by N. K. Skliarenko [4, p. 153], we took into account the views of I. P. Zadorozhna [2] on the types of exercises for individual work. Developing the ideas suggested by I. P. Zadorozhna [2, p. 291-293], we provided the following types of exercises for each group.

Group 1 comprises the following exercises and tasks:

- defining the correlation between the given sentences and new grammatical structures used in them. In our case it is important to add defining relation between the given grammatical structure in English and its correlate in German;

- imitating speech samples containing new grammatical structures by agreeing or disagreeing with statements, stating whether certain grammatical structures correct or incorrect etc.;

- reproducing new grammatical structures by means of substitution for sentence construction using a given model [2, p. 291-292].

- Group 2 contains the following exercises and tasks:

- changing sentences according to the type of grammatical category to be substituted and producing all the following changes in the sentence (e.g. Rewrite the sentences in the passive; Rewrite the story using the past forms of the verbs);

- paraphrasing sentences by substitution of one grammatical form for the other using key words or without them (e.g. Tom haven't finished painting the house yet. Key word - still: Tom is still painting the house.);

- making choice of grammatical forms from the given options and filling in the gaps in the sentence or text;

- making grammatical errors correction;

- filling in the gaps in the sentence or text with an appropriate article/adjective/pronoun/form of the verb/preposition etc.;

- filling in the gaps in the sentence or text with words given in the brackets using their correct grammatical forms;

- making up sentences by means of matching the beginning from column A with the ending from column B;

- translating the words, phrases and sentences from the first foreign language into the second foreign language and vice versa, and also translate from the native language into the second foreign language and vice versa;

- constructing sentences using a given model [2, p. 292]. Group 3 includes the following exercises and tasks:

a) holding discussions, constructing description or story using certain grammatical structures. These exercises are usually supported with pictures or certain prompts. For example the students may be asked to look at the pictures of people in certain life situations and to make logical assumptions about their occupation (Example: Is she a student? - She can't be a student. She must be an artist.), describe their appearance, speak or write about their actions using appropriate tense forms;

b) making up sentences using certain grammatical structures according to the corresponding situation and using them for writing or telling a story (Example: Sara Philips has inherited an old farm and she has decided to turn it into club. Look at the prompts and make sentences using the present 
perfect passive as in the example. Example: the walls/painted. - The walls have been painted [7, p. 91]);

c) retelling the previously read or heard text using new grammatical structures;

d) making up dialogues or delivering speeches using new grammatical structures;

e) filling in the gaps in a written text with the words in appropriate grammatical forms using recordings that contain additional information [2, p. 292-293].

The following several examples of exercises for forming productive grammatical skills within independent work were developed using several sources $[7 ; 8 ; 10]$.

Example 1, group 1 [8, p. 26]:

Purpose: developing usage of going to structure in interrogative sentences, training positive and negative short answers.

Type: substitution for sentence construction on a given model.

Implementation: individually.

Control: self-control (with the help of the keys).

Instruction: Jane and George have some plans for their summer holidays.

a) Look at prompts in the table, ask and answer questions using be going to, as in the example. b) Work in pairs. Look at prompts in the table, ask each other questions about your plans for summer holidays, as in the example.

\begin{tabular}{|l|l|l|l|l|}
\hline & Jane & George & You & Your partner \\
\hline 1. go abroad & + & & & \\
\hline travel in his own country & & + & & \\
\hline 2. travel by car & & + & & \\
\hline travel by plane & + & & & \\
\hline 3. bring swimming costume & + & & & \\
\hline bring hiking boots & & + & & \\
\hline 4. go with friends & + & & & \\
\hline go with his family & & + & & \\
\hline 5. stay at a hotel & + & & & \\
\hline go camping & & + & & \\
\hline 6. swim in the sea & + & & & \\
\hline go for a walk in the countryside & & + & & \\
\hline
\end{tabular}

- Is Jane going to travel by car?

- No, she isn't. She is going to travel by plane.

- Is George going to travel by car?

- Yes, he is.

Example 2, group 2 [10, p. 96-97]:

Purpose: automitizing the usage of certain tense forms, developing grammatical awareness by means of contrasting languages, developing reflective skills.

Type: producing new grammatical structures by means of translation.

Implementation: individually.

Control: by the teacher, self-control (with the help of the keys).

Instruction: a) Translate the following sentences into English using Present Simple or Present Continuous Tense. Pay attention to the situations when the Present Continuous Tense is used. Note the differences in tense forms in German and English.

1. Er spielt gerade Klavier.

2. Tomas und Marie trinken gerade Tee.

3. Was machst du heute am Abend?

4. Wohin geht er jetzt?

5. Jetzt liest Die Großmutter ein Buch und ihr Enkel spielt Fußball.

6. Katerina möchte in England studieren, also lernt sie Englisch.

7. Sieh! Es regnet.

8. Hör zu! Sie singt im Garten.

9. Sabine ist müde, sie geht jetzt ins Bett.

10. Hans liest gern, also liest er gerade ein interessantes Buch. 
11. Sie arbeitet jetzt nicht, sie sucht nach ihrem Bruder.

12. Gehen sie heute Abend ins Theater? - Nein. Wir gehen nicht ins Theater, wir besuchen unsere Tante.

b) Fill in the table. Label the situations the groups of sentences with the Present Continuous Tense represent.

\begin{tabular}{|l|l|}
\hline Sentence number & Types of use \\
\hline $1,2,4,5,7,8,9,11$ & \\
\hline 3,12 & $\begin{array}{l}\text { Actions happening in a period around now, but not actually at the } \\
\text { moment of speaking }\end{array}$ \\
\hline 6,10 & \\
\hline
\end{tabular}

Example 3, group 3:

Purpose: building knowledge how to use grammatical structures in the given context, developing grammatical awareness, developing reflective skills.

Type: constructing description or story using certain grammatical structures.

Implementation: individually.

Control: by the teacher, self-control.

Instruction: Choose the picture of one of your relatives or friends ten years ago and the one in present. Compare the way he or she used to look and how he or she looks nowadays, what he or she used to do ten years ago and does now, where he or she used to live and lives now, what his or her eating habits used to be and what are they now, how he or she used to spend his or her free-time and does it now. Write a short article about your relative or friend using used to be structure.

Thus, the subsystem of exercises for forming productive grammatical competence in the process of teaching English after German can become a means facilitating the process of acquiring English grammar and organizing students' independent work. The suggested subsystem of exercises for forming productive grammatical competence consists of three groups of exercises and covers three stages of the grammatical competence development: preparatory, stereotypical and variational.

Further research is dedicated to the development of methodology of forming productive grammatical competence of prospective teachers learning English after German within independent work.

\section{ЛІТЕРАТУРА}

1. Загальноєвропейські Рекомендації з мовної освіти: вивчення, викладання, оцінювання / науковий редактор українського видання доктор пед. наук, проф. С. Ю. Ніколаєва. - К.: Ленвіт, 2003. - 261 с.

2. Задорожна І. П. Теоретико-методичні засади організації самостійної роботи майбутніх учителів 3 оволодіння англомовною комунікативною компетенцією: дис. ... д-ра. пед. наук: 13.00 .02 / І. П. Задорожна - К., 2012. - 770 с.

3. Методика навчання іноземних мов і культур: теорія і практика: підручник для студ. класичних, педагогічних і лінгвістичних університетів; за заг. ред. С. Ю. Ніколаєвої / О. Б. Бігич, Н. Ф. Бориско, Г. Е. Борецька та ін. - К.: Ленвіт, 2013. - 590 с.

4. Скляренко Н. К. Методика формування іншомовної граматичної компетенції у студентів мовних спеціальностей / Н. К. Скляренко // Методика формування міжкультурної іншомовної комунікативної компетенції: курс лекцій: навч.-метод. посіб. для студ. мовних спец. осв.-кваліф. рівня «магістр»; за ред. С. Ю. Ніколаєвої / О. Б. Бігич, Н. Ф. Бориско, Г. Е. Борецька та ін. - К.: Ленвіт, 2011. - С. 141-160.

5. Скляренко Н. К. Методика формування іншомовної граматичної компетенції в учнів загальноосвітніх навчальних закладів / Н. К. Скляренко // Іноземні мови. - 2011. - № 1. - С. 15-25.

6. Dirven R. Pedagogical Grammar / R. Dirven // Language Teaching, 1990. - Vol. 23, № 1. - P. 1-18.

7. Dooley J. Grammarway. Level 2 with answers / J. Dooley, V. Evans. - Newbury: Express Publishing, 1999. - $192 \mathrm{p}$.

8. Evans V. Enterprise: Grammar Level 2. Student's Book / V. Evans, J. Dooley. - Newbury: Express Publishing, 1999. - $95 \mathrm{p}$.

9. Hedge T. Teaching and Learning in the Language Classroom / T. Hedge. -Oxford, Oxford University Press, 2000. -448 p.

10. König E. Understanding English-German Contrasts / E. König, V. Gast. - 3., neu bearbeitete und erw. Aufl. Berlin: Erich Schmidt Verlag, 2012. - 364 p. - (Grundlagen der Anglistik und Amerikanistik; Bd. 29.)

11. Richards J. C. Key Issues in Language Teaching / J. C. Richards. - Cambridge; Cambridge University Press, 2015. $826 \mathrm{p}$. 


\title{
REFERENCES
}

1. Zahanoyevropeyski Rekomendatsiyi z movnoyi osvity: vyvchennya, vykladannya, otsinyuvannya [Common European Framework of Reference for Languages: Learning, Teaching and Assessment. Ukrainian version]. S. Yu. Nikolayeva (sci. ed.). Kyiv, Lenvit, 2003. 261 p.

2. Zadorozhna I. P. Teoretyko-metodychni zasady orhanizatsiyi samostiynoyi roboty maybutnikh uchyteliv z ovolodinnya anhlomovnoyu komunikatyvnoyu kompetentsiyeyu. Dokt. Diss. [Theoretical and Methodological Foundations of Future Teachers' Self-Study Work Organization on Acquiring Communicative Competence in English. Doct. Diss.]. Kyiv, 2012. 770 p.

3. Bihych O. B., Borysko N. F., Boretska H. E. Metodyka navchannya inozemnykh mov i kultur: teoriya i praktyka [Methods of Teaching Languages and Cltures: Theory and Practice]. S. Yu. Nikolayeva (ed.). Kyiv, Lenvit, 2013. 590 p.

4. Sklyarenko N. K. Metodyka formuvannya inshomovnoyi hramatychnoyi kompetentsiyi u studentiv movnykh spetsialnostey [Methods of forming foreign language grammatical competence of philology students]. Metodyka formuvannya mizhkulturnoyi inshomovnoyi komunikatyvnoyi kompetentsiyi: Kurs lektsiy: [Methods of forming intercultural foreign language communicative competence: Course of lectures]. Kyiv, Lenvit Publ., 2011. pp. 141-160.

5. Sklyarenko N. K. Metodyka formuvannya inshomovnoyi hramatychnoyi kompetentsiyi $\mathrm{v}$ uchniv zahalnoosvitnikh navchalnykh zakladiv [Methodology of forming foreign language grammatical competence of secondary school students]. Inozemni movy. 2011. Vol. 1. pp. 15-25.

6. Dirven R. Pedagogical Grammar. Language Teaching, 1990, Vol. 23, Issue 1, pp. 1-18.

7. Dooley J., Evans V. Grammarway. Level 2 with answers. Newbury: Express Publishing, 1999. 192 p.

8. Evans V., Dooley J. Enterprise: Grammar Level 2. Student's Book Newbury: Express Publishing, 1999. 95 p.

9. Hedge T. Teaching and Learning in the Language Classroom. Oxford, Oxford University Press. 2000. 448p.

10. König E., Gast V. Understanding English-German Contrasts. Grundlagen der Anglistik und Amerikanistik; Bd. 29. (3., neu bearbeitete und erw. Aufl.). Berlin, Erich Schmidt Verlag, 2012, 364 p.

11. Richards J. C. Key Issues in Language Teaching. Cambridge, Cambridge University Press, 2015, 826 p.

Стаття надійшла в редакиію 22.05.2018 p

удк 373.5.016:811.161.2

НАТАЛІЯ СРМАК

gumen.natalya@gmail.com аспірантка

Бердянський державний педагогічний університет

м. Бердянськ, вул. Шмідта, 4

\section{ЗМІСТ І ЗАВДАННЯ ЕКСПЕРИМЕНТАЛЬНО-ДОСЛІДНОГО НАВЧАННЯ У ПРОЦЕСІ ФОРМУВАННЯ ТЕКСТОТВОРЧИХ УМІНЬ УЧНІВ ЗАКЛАДІВ ЗАГАЛЬНОЇ СЕРЕДНЬОЇ ОСВІТИ ОСНОВНОЇ ЛАНКИ (НА ПРИКЛАДІ МОРФОЛОГІЇ УКРАЇНСЬКОЇ МОВИ)}

\begin{abstract}
Проаналізовано взаємозв'язок складових формування текстотворчих умінь з морфології украӥнської мови із завданнями експериментально-дослідного навчання. Представлено відповідність иих завдань із функціональними компонентами, а саме: розумовою, планувальною, помуковою, інформаційною, систематизуючою, вибірковою, очіночною й аналітичною. Охарактеризовано запропоновані функціональні компоненти з використанням науково-методичного підходу, основними сутнісними ознаками якого є оцінки кожної окремої функціональної компоненти експериментальнодослідного навчання в контексті формування текстотворчих умінь на уроках морфології української мови. Наведено показники вказаних функиіональних компонент на основі запропонованих творчих завдань щзодо формування текстотворчих умінь учнів закладів загальної середньої освіти основної ланки на прикладі морфологї̈ украӥнської мови.
\end{abstract}

Ключові слова: текстотворчі уміння, текстотворча діяльність, функиіональна компонента, морфологія украӥнської мови, експериментально-дослідне навчання. 